
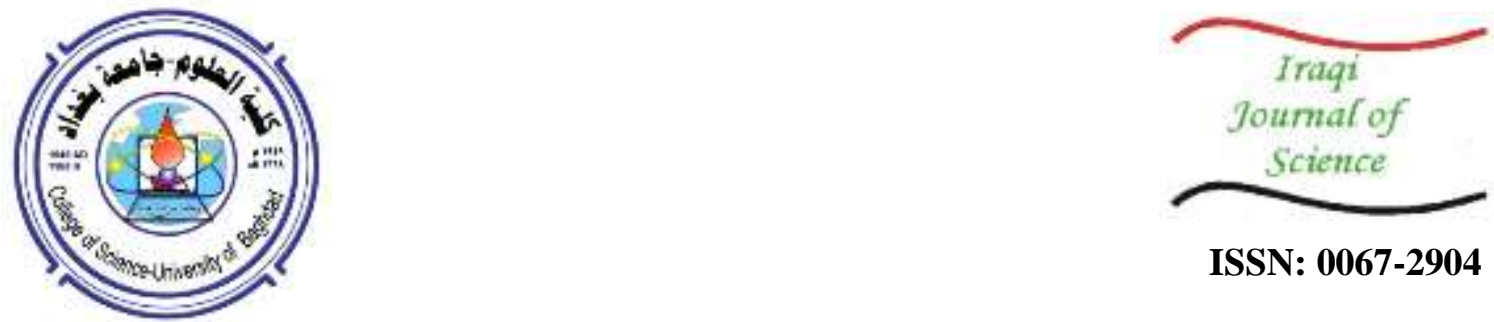

ISSN: 0067-2904

\title{
Effect of Natural Phytase, Fermentation, and Baking Processes on Phytate Degradation in Wheat Bread Manufactured from Local Mills Flour
}

\author{
Jassim M. Nasser*, Ezuldeen K. Hammood \\ Food Science, College of Agricultural Engineering Sciences, University of Baghdad, Baghdad, Iraq
}

\begin{abstract}
The present study aims to investigate the effect of wheat natural phytase, fermentation and baking processes in the destruction of phytic acid during the process of making wheat bread for some Iraqi mills. The concentration of phytic acid was $(850.32,802.14,531.84 \mathrm{mg} / 100 \mathrm{~g})$ for the flour of AL-Brairie, AL-Nesr and AL-Al-Doura mills respectively. At the end of the fermentation processes, the decrease in the concentration of phytic acid in the samples produced from the flour obtained from the three mills was $(47.06,26.98,40.00 \%)$ respectively, while inorganic phosphorus concentration in all treatments increased by 32.4, 42.37 and $36.21 \%$, respectively. It was found that the activity of wheat natural phytase enzyme varies according to the type of mill and the enzyme has been destroyed after the baking process for all treatments. It is clear that, with the effect of wheat natural phytase enzyme and fermentation and baking processes, the concentration of phytic acid may be reduced when preparing wheat bread for some mills by $(26-47 \%)$.
\end{abstract}

Keywords: Phytic acid, Iraqi Wheat, Phytase enzyme, Fermentation Treatments, Inorganic Phosphorus.

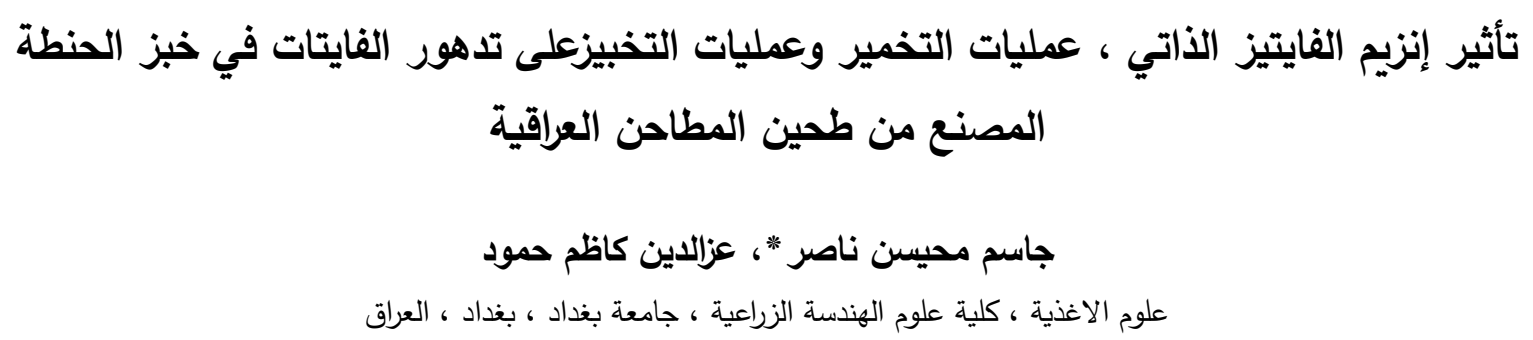

الخلاصة

هدفت الدراسة الحالية للتعرف على تأثير أنزيم الفايتيز الذاتي وعمليات التخمير وعمليات التخبيز في

تحطيم حامض الفايتيك خلال عمليات تصنيع خبز القهح لبعض المطاحن العراقية.كان تركيز حامض الفايتيك

بواقع (850.32، 802.14 ، 531.84 ملغم/ · • (غم) لطحين مطاحن البراري والنسر والدورة على التوالي.

عند انتهاء عمليات التخمير كانت نسبة الانخفاض في تركيز حامض الفايتيك في العينات المصنعة من

الطحين المتحصل من المطاحن الثلاثة بواقع ( 47.06 ، 26.98 ، 20.00 \% 40.

ارتفاع في تركيز الفنفور اللاعضوي في المعاملات جميعها بواقع (32.4 , 42.37 , 36.21\%) على بلى

التوالي.وجد أن فعالية أنزيم الفايتيز الذاتي تختلف باختلاف نوع المطحنة وقد تحطم الإنزيم بعد انتهاء عملية

التخبيز لكافة المعاملات .من الواضح أنه مع تأثير إنزيم الفايتيز الذاتي وعمليات التخمير والخبز ، يمكن تقليل

$$
\text { تركيز حامض الفايتيك عند إعداد خبز القهح لبعض المطاحن بنسبة (26-47٪). }
$$

*Email: dr-jassim6699@yahoo.com 


\section{Introduction}

The process of making bread and its quality mainly depends on the components involved in its composition, which include flour, yeast, salt and water, as well as other additives that can be used to improve the composition of the dough and its ability to form and carry out the manufacturing processes as well as to improve the quality of the product in terms of bread volume and crump composition, all of these attributes are related to the properties of the proteins, carbohydrates, and pigments found in the flour [1].The enzyme treatment of flour was an important alternative to obtaining the required changes in the composition of the dough to improve its functional properties.

There are many types of bread whose quality and nutritional value depends on flour extraction rates. White bread has an extraction rate of $72 \%$, it contains a small percentage of vitamins, mineral salts, and fiber (low nutritional value). Another type of high-value bread is known as whole wheat bread (100\% extraction), which is an important source of inorganic materials such as iron, zinc and magnesium [2]. At present, societies have realized that the consumption of high-fiber products, including whole-wheat bread or bran-fortified meals, has a positive impact on human health. Studies have shown that eating enough whole foods gives protection against coronary heart disease, certain types of cancer, diabetes of the second type, but these products also provide anti-food factors, such as inhibitory factors and the factors that inhibit the absorption of metals such as phytate.

Phytatemyo-inositol 1, 2, 3, 4, 5, 6-hexakisdi hydrogen phosphate $\left(\mathrm{C}_{6} \mathrm{H}_{18} \mathrm{O}_{24} \mathrm{P}_{6}\right)$ and their molecular weight $660.58 \mathrm{~g} / \mathrm{mol}$ are biologically active compounds that have the ability to form insoluble complexes by binding and inhibiting the absorption of compounds and metal elements charged with a positive charge such as protein, starch and metal elements by the organism in biological conditions by forming ionic bonds and covalent with phosphate aggregates associated with the inositol ring [3].

There are several ways to reduce the level of phytate, including fermentation and increase the added yeast, prolong the fermentation period to produce sour dough, add phytase enzyme to the dough, use different strains of microorganisms that reduce the acidity of the dough to ensure the effective work of the enzyme such as Lactic acid bacteria. The phytic acid reduction rate during the period of manufacture depends on the effectiveness of the phytase enzyme found in the wheat and yeasts, as well as several factors contributing to the breakdown of the phytate, such as the size of the minced wheat minutes, $\mathrm{pH}$, water content and the length of the fermentation [4].

The present study aims to investigate the effect of fermentation and baking time and the effectiveness of the phytase enzyme in reducing the level of antinutrition (phytic acid) in bread manufactured from local mill flour.

\section{Material \& Method}

Preparation of wheat flour: From three different local mills flour were collected, all were kept in cooling $( \pm 4 \mathrm{~m})$. The following physical and chemical tests were performed: Proximate compositions of all flour samples were studied using AACC methods [5]. Total carbohydrate was calculated by difference.

Bread (loaf) preparation: The bread making performances of the flours were determined using the straight dough AACC method No. 10-10 B [6] with a slight modification. The bread formula for each loaf included $100 \mathrm{~g}$ wheat flour, yeast, salt, sugar, fat and an adequate amount of water to obtain dough of optimum consistency. The bread making procedure included mixing, at low speed for 2 min followed by mixing the medium for 3 minutes using a spiral arm mixer, and a proving time of 180 min at $36^{\circ} \mathrm{C}$ and $70 \%$ relative humidity (r. h.) and baking for $20 \mathrm{~min}$ at $210^{\circ} \mathrm{C}$. in a convection oven. Baked loaves were cooled down at room temperature for $60 \mathrm{~min}$, wrapped in a plastic film and then stored at room temperature $\left(20^{\circ} \mathrm{C}\right)$. The treatments included in this experiment were:

T1: Al-Brairie flour mill with the basic ingredients.

T2: Al-Nesr flour mill with the basic ingredients.

T3: Al-Doura flour mill with basic ingredients.

-Sensory Evaluation of Bread (loaf): The evaluation form mentioned in Alzubaidy [7]was used.

- Determination of phytic acid (PA): Phytic acid was estimated according to the method described by Latta and Eskin [8], referred to by Almihyawi [3].

- Determination of inorganic phosphorus: Inorganic phosphorus was estimated according to the method cited by Chen et al. [9], referred to by Almihyawi [3]. 
- pH measurement for flour and dough: AACC method 02-52 [10] was adopted by mixing $10 \mathrm{~g}$ of flour or dough with $100 \mathrm{ml}$ distilled water ( $\mathrm{pH}$ 7), then homogenized by German Heidolph Made at 26000 speed (cycle / minute) for 2 minutes and left for 5 minutes, then $\mathrm{pH}$ was measured.

- Determination of wheat-phytase activity in dough: The enzyme activity was determined according to Sedaghati et al., [11] method. with a simple modification where the dough samples were lyophilized and the phytase enzyme was extracted. One g of dry dough dissolved in $5 \mathrm{ml}$ of $0.2 \mathrm{M}$ acetate buffer $(\mathrm{pH}=5.4)$, and then homogenized at a speed of 20,000 rpm / min using German Heidolph Made for 2 minutes(It is preferable to place samples in an iced water bath to maintain the temperature of the solution during homogenization), the samples were then placed in the refrigerator for the enzyme extraction at $\left(5^{\circ} \mathrm{c}\right)$ for 18 hours on the magnetic stirrer device, the precipitate was then isolated after filtration of the leachate by centrifuge at $40000 \mathrm{Xg}$ for 30 minutes and at $\left(4^{\circ} \mathrm{C}\right)$, the process was repeated to the leachate at $15000 \mathrm{Xg}$ speed and at the same time and temperature. The enzyme activity was expressed as the amount of inorganic phosphorus released in accordance with the Fisk and Subbarow method of [12], referred to by [3]. The comparison tube was prepared by adding $0.1 \mathrm{ml}$ of leachate (zero hour or moment of preparation) to $0.9 \mathrm{ml}$ of the substrate. The reaction was stopped directly by adding $1 \mathrm{ml}$ of TCA solution (10\%), all tubes were incubated in a water bath at $50^{\circ} \mathrm{C}$ for half an hour. The enzymatic reaction was stopped by adding $1 \mathrm{ml}$ of TCA solution at $10 \%$, At the end of time, add the color detector, which is made up of 4 volumes[ $\left(5.5 \%\right.$ Sulfuric acid $\mathrm{H}_{2} \mathrm{SO}_{4}(\mathrm{~V} / \mathrm{V})$ dissolved in it $1.5 \%(\mathrm{~W} / \mathrm{V})$ ammonium molbidate in an ice bath)+ 1 volume of $2.7 \%(\mathrm{~W} / \mathrm{V})$ Hydrothermal Sulfate $\mathrm{FeSO}_{4} \cdot 6 \mathrm{H}_{2} \mathrm{O}$ )], then centrifuge the tubes at $5000 \mathrm{rpm} / \mathrm{min}$ for 15 minutes, and read the optical absorption intensity of the violet color at a wavelength of $700 \mathrm{~nm}$ in the optical spectrometer. The enzyme activity unit is defined as the amount of enzyme that releases one $\mu \mathrm{g}$ of inorganic phosphorus per $\mathrm{ml}$ of sodium phytate solution under experimental conditions.

\section{Results and discussion}

\section{Chemical properties of flour forms:}

Table-1 shows the percentages of the chemical components of the flour used in this study. The percentage of moisture in the Al-Brairie, Al-Nesr and Al-Doura flours was 11.9, 11.5 and 11.4\%, respectively, which is within the favorite range of bakeries $(11.5-15.2 \%)$ [13]. This helps greatly in storing flour without damage. Moisture is an important factor in determining the quality of the flour and its water absorption. The protein content was $11.7,11.2$ and $10.1 \%$, respectively. Protein is of great importance in determining product quality, the table shows the superiority of the first and second type flour in this component compared to the third type. These results were consistent with [1], who indicated that the percentage of soft wheat protein ranged between 9-12\%. The protein content of grains is a quality characteristic affected by the environment and is one of the basic criteria for the quality of wheat grains, which depends mainly on the genetic factors of class and species and on the climatic and agricultural conditions prevailing during the growth. The same table also showed that the fat percentage were $(1.48,1.38,1.06 \%)$ respectively. Several studies have confirmed the importance of flour fat in bread making and the rheological properties of the dough, despite their low concentration compared to other flour ingredients.

Ash percentages for flour samples were $1.32,1.19,0.76 \%$, respectively, which is similar to that of Pozrl et al. [14].Ash content is associated with the quality of the milling process. It is a strong indicator of flour color and purity. The efficiency of the milling process is determined by knowing the flour content of the ash mainly associated with the amount of bran in the wheat grain, which is usually 0.4-2.0\%, calculated on the basis of 14\% moisture [15]. Iuliana et al. [16] found that the percentage of carbohydrates for wheat and the general average was (65-75\%) and was identical to what was found in the flour of the treatments under study.

Table 1-The chemical components of the flour from Al-Brairie, Al-Nesr and Al-Doura mills

\begin{tabular}{|c|c|c|c|c|c|c|c|}
\hline Mills & Carbohydrate & Ash & Protein & Fat & Moisture & $\begin{array}{c}\text { Phytic } \\
\text { acid }\end{array}$ & $\begin{array}{c}\text { Inorganic } \\
\text { phosph. }\end{array}$ \\
\hline $\begin{array}{c}\text { Al- } \\
\text { Brairie }\end{array}$ & 73.6 & 1.32 & 11.7 & 1.48 & 11.9 & 850.32 & 6.03 \\
\hline $\begin{array}{c}\text { Al- } \\
\text { Nesr }\end{array}$ & 74.73 & 1.19 & 11.2 & 1.38 & 11.5 & 802.14 & 7.26 \\
\hline
\end{tabular}




\begin{tabular}{|l|c|c|c|c|c|c|c|}
\hline $\begin{array}{c}\text { Al- } \\
\text { Doura }\end{array}$ & 76.68 & 0.76 & 10.1 & 1.06 & 11.4 & 531.84 & 10.10 \\
L.S.D. & - & - & - & - & - & $103.66^{*}$ & $2.094^{*}$ \\
\hline
\end{tabular}

It is noted from Table-1 that the percentage of phytic acid in flour varies from one mill to another $(850.32,802.14,531.84) \mathrm{mg} / 100 \mathrm{~g}$ flour for Al-Brairi, Al-Nesr and Al-Doura mills respectively. It is also noted from the same table that the percentages of inorganic phosphorus were $(6.03,7.26$, and 10.10) for the above species respectively.

These results of PA content were similar to those of the published studies. Pozrl et al. [14] noted that the content of phytic acid in whole flour extract was $946 \mathrm{mg} / 100 \mathrm{~g}$. While Didar [17] found that the content of phytic acid $(894.66 \mathrm{mg} / 100 \mathrm{~g})$ in flour with an extraction rate of $98 \%$. The results of phosphorus were lower than that found by Al-Mihyawi [3], which found that the concentration of organic phosphorus in the whole flour of the varieties (Iba 99, Rasheed, Tamos, Abu Ghraib, Turkish flour "Moamal") were (29.18, 25.15, 23.89, 20.85, $22.83 \mathrm{mg} / 100 \mathrm{~g})$, respectively. This reduction may be due to the low extraction ratio compared to the whole flour, as indicated by the chemical composition of these samples under study.

\section{- Determination of $\mathbf{p H}$ in flour and dough:}

Table-2 shows $\mathrm{pH}$ values in the flour and dough of the three treatments under study during hours of fermentation and after baking. The $\mathrm{pH}$ of Al-Brairi, Al-Nesr and Al-Doura flour mills was 6.62, 6.46, 6.71 , respectively. When preparing the dough for the three treatments, the $\mathrm{pH}$ values were highest at the hour of preparation $(6.46,6.39,6.51)$ respectively. From the data, at the end of the first hour of the fermentation process, there was a decrease in the $\mathrm{pH}$ values of the three treatments dough. $\mathrm{T} 1$ achieved the highest decrease (6.33) compared with the other treatments $(6.29,6.41)$ respectively, as did the end of the fourth hour.

The decrease in $\mathrm{pH}$ values may be due to yeast's ability to ferment sugars available in flour, as well as added sugar, carbon dioxide production and formation of weak acids. This reduction has had a positive effect on providing favorable conditions for the work of the phytase enzyme. Studies have indicated that raising the added yeast or prolonging the fermentation period to produce acid bread also contributes to this $[18,19]$.

Table 2-PH values in the flour and dough of the three treatments under study.

\begin{tabular}{|cccccccc|} 
Mills & Flour & $\begin{array}{c}\text { dough } \\
\text { Zero hr. }\end{array}$ & $\begin{array}{c}\text { dough } \\
\text { First hr. }\end{array}$ & $\begin{array}{c}\text { Dough } \\
\text { Second hr. }\end{array}$ & $\begin{array}{c}\text { dough } \\
\text { Third hr. }\end{array}$ & $\begin{array}{c}\text { dough } \\
\text { Fourth hr. }\end{array}$ & After baking \\
\hline Al-Brairi & 6.62 & 6.46 & 6.42 & 6.38 & 6.37 & 6.33 & 6.31 \\
\hline Al-Nesr & 6.46 & 6.39 & 6.37 & 6.34 & 6.31 & 6.29 & 6.28 \\
\hline Al-Doura & 6.71 & 6.51 & 6.49 & 6.49 & 6.43 & 6.41 & 6.39 \\
\hline
\end{tabular}

\section{- Determination of phytic acid in the dough:}

Table-3 shows the amount of phytic acid (mg/100g) in the dough which made of experimental flour during fermentation hours. It is noted that the highest percentage of phytic acid in the dough at zero hour was in T1 treatment dough and the lowest in the dough of T3 treatment. This indicates that the flour with the high phytic acid content gave dough of the same specifications despite the difference in the amount of water added to each treatment. The amount of phytic acid when preparing the dough for the three treatments $(680,630,450) \mathrm{mg} / 100 \mathrm{~g}$ respectively. It is noted from this table that the fermentation process reduced the amount of phytic acid in all treatments in different rates. At: the end of the first hour of the fermentation process, the amount of reduction in the phytic acid for the three treatments were $(16.18,1.59,17.78 \%)$ respectively. The highest reduction in phytic acid was in T3 treatment dough, whereas at the end of the fourth hour the highest reduction was in T1 treatment dough. The decline in the three treatments was $(47.06,26.98,40.00 \%)$ respectively after the end of the fourth hour of fermentation. The reason for this decrease or degradation in phytic acid is the increased activity of the phytase enzyme in the dough as a result of the favorable conditions for its work. The ratios of the existence of this enzyme vary according to the plants and their parts and types of each class so it is noted that the amount of the rates of decline varied between different treatments. 
Yeast has the potential to reduce $\mathrm{pH}$ as a result of fermentation of sugars, production of carbon dioxide and carbon monoxide and formation of weak acids, and thus have a positive effect in providing conditions suitable for the work of the phytase enzyme. Some studies have indicated that the optimal $\mathrm{pH}$ for the action of wheat phytase was 5.15, other researchers have suggested that vegetable phytase can work at a range of $\mathrm{pH}$ values(4-6). It has been noticed (Table-4), that the $\mathrm{pH}$ of all treatments was decreased. This findings were in agreement with that of confirmed by $[19,20]$. Some related studies have suggested that the yeast used in fermentation can also produce phytase enzyme but each has ideal conditions [21]. Since the type and percentage of yeast is constant in all the treatments, the main reason for the differences in the ratios of the PA decline between the species is attributed to the difference in the ratio of the phytase enzyme that exists naturally in the flour and possibly due to the difference in extraction rates of flour, because the phytate and phytase enzyme located in the bran layers Al-mihyawi, [3]. Fretzdorff and Brummer [22] found that $\mathrm{pH}$ was the most important factor in reducing the content of phytic acid during the baking process and concluded that the value of $\mathrm{pH} 4.3-4.6$ and $55^{\circ} \mathrm{C}$ gave the best reduction of phytic acid when making sour dough.

Table 3-Phytic acid content $(\mathrm{mg} / 100 \mathrm{~g})$ in the dough of the treatments under study during fermentation hours

\begin{tabular}{|cccccc|}
\hline Mills & Zero hr. & First hr. & Second hr. & Third hr. & Fourth hr. \\
\hline Al-Brairi & 680 & 570 & 440 & 380 & 360 \\
\hline Al-Nesr & 630 & 620 & 530 & 490 & 460 \\
\hline Al-Doura & 450 & 370 & 340 & 320 & 270 \\
\hline L.S.D & $87.53^{*}$ & $116.45^{*}$ & $79.31^{*}$ & $82.76^{*}$ & $67.27^{*}$ \\
\hline
\end{tabular}

\section{- Determination of inorganic phosphorus in the dough:}

Table-4 shows the concentration of inorganic phosphorus in the experimental dough samples during different fermentation hours. The highest percentage of inorganic phosphorus in $\mathrm{T} 3$ treatment dough was at zero time. The amount of phosphorus in the dough made from Al-Brairi, Al-Nesr and Al-Doura mill flour samples were $(16.76,19.54,41.15 \mathrm{mg} / 100 \mathrm{~g})$. It is clear that the process of fermentation resulted in an increase in the proportion of inorganic phosphorus in all treatments in a different ratio.

The phytase available in flour is responsible for the degradation of phytic acid and the production of inorganic phosphorus, but at different rates depending on the proportion and activity of this enzyme in each treatment [23].

The amount of inorganic phosphorus formed in the dough depends on several factors, including the availability of enzymes (phytase and phosphatases) and conditions for their effectiveness. The results of this study are similar to those found by Al-Mihyawi [3].

Table 4-inorganic phosphorus content $(\mathrm{mg} / 100 \mathrm{~g})$ in the dough of the treatments under study during fermentation hours

\begin{tabular}{|cccccc|}
\hline Mills & Zero hr. & First hr. & Second hr. & Third hr. & Fourth hr. \\
\hline Al-Brairi & 16.76 & 19.67 & 20.99 & 21.85 & 22.19 \\
\hline Al-Nesr & 19.54 & 19.75 & 20.27 & 21.50 & 27.82 \\
\hline Al-Doura & 41.15 & 45.12 & 50.45 & 51.44 & 56.05 \\
\hline L.S.D & $7.42^{*}$ & $8.05^{*}$ & $7.32^{*}$ & $7.69^{*}$ & $6.44^{*}$ \\
\hline
\end{tabular}

\section{-Determination of the effectiveness of the phytase enzyme in the dough of the treatments under study:}

Table-5 shows that there are clear differences in the values of the activity of wheat natural phytase enzyme in the dough of the three treatments under study during the different fermentation hours, depending on the $\mathrm{pH}$ of the dough and the extraction rates of flour. This is confirmed by many previous studies, which showed high efficacy of phytase enzyme at higher extraction rates of flour[11]..The efficiency rate during the first hour of the three treatments $(4,2,1)$ unit $/ \mathrm{g}$ dough respectively, while at four hours became $(5,5,1)$ unit / $g$ dough respectively. 
The increase in inorganic phosphorus liberated by phytic acid degradation during the four fermentation hours is directly related to the increase in enzyme activity. The rate of hydrolysis of phytic acid after the first hour of the three treatments were $(17.78$ ، 1.59 ، 16.18) respectively, while after the fourth hour was $(47.06,26.98,40.00) \%$. This is due to the difference in the extraction rate of the flour used and the difference in the amount of decrease in $\mathrm{pH}$ values during the fermentation process. Similar finding was mentioned by [3, 17, 24, 25].

The effect of the enzyme was significantly reduced in bread and disappeared in all treatments because the enzyme was severely affected by the baking heat $\left(210^{\circ} \mathrm{C} / 20 \mathrm{~min}\right)$.

Table 5-The activity of phytase enzyme during fermentation and baking hours (unit / g)

\begin{tabular}{|c|c|c|c|}
\hline Fermentation hours & Al-Brairi mill & Al-Nesr mill & Al-Doura mill \\
\hline Zero hr. & 4 & 2 & 1 \\
\hline First hr. & 3 & 2 & 1 \\
\hline Second hr. & 6 & 2 & 1 \\
\hline Third hr. & 6 & 2 & 1 \\
\hline Forth hr. & 5 & 5 & 1 \\
\hline bread & 0 & 0 & 0 \\
\hline
\end{tabular}

\section{-The sensory characteristics of the experimental bread produced from local flour mills:}

Tables-(6,7) shows the internal and external characteristics of experimental bread made of the flour produced by local mills, the specific volume, color of crust, symmetry of form, evenness of bake, color of crumb, texture of crumb, grain of crumb, aroma and taste. T1 and T2 treatments showed significant differences compared to T3 treatment of the volume and specific volume characteristics, while there were no significant differences in the weight of bread among the treatments. The reduction in the specific volume of T3 treatment may be due to the fact that the product is made from wheat with high amylase content. This is confirmed by a breakdown in breadcrumbs and difficult to handle during the preparation.

As shown from the Table-7 there were no significant differences in external characteristics, such as the color of the crust, symmetry of form and evenness of bake for all treatments. The color of the crust in the final product depends mainly on the temperature of the baking process and the amount of sugar remaining in the dough because there are two important reactions in the baking process: the first reaction is the carmilization and the second is the millard reaction. Both reactions depend on the sugar available in the dough mixture [1]. As for the color of the pulp, T3 treatment was significantly different with $\mathrm{T} 1$ and $\mathrm{T} 2$ treatments, as it was more white, while the characteristics of grain of crumb showed significant differences as T1 and T2 treatments had a better distribution of gaseous cells and their homogeneity compared with T3 treatment. The same table shows that the aroma and taste and texture of crumb did not have any significant differences.

The experimental bread obtained from $\mathrm{T} 1, \mathrm{~T} 2$ treatments were characterized by a solidity compared with the experimental bread for T3 treatment. The bread stiffness increased with the addition of the fiber sources and the increase in the extraction percentages (depending on the degree of color and chemical composition). Pyler [26] confirmed that the fiber in the bread leads to a decrease in the amount of gluten and thus reduces the ability to store gas in the dough resulting in a reduction in the elasticity of the resulted bread. These results were consistent with Póltorak and Zalewska [25].\&Hammood and Nasir[19]. They noted that increasing the percentage of oats and wheat fiber and higher extraction rate significantly increases the hardness of bread. Majzoobi et al. [27] found that increasing the fiber ratio and increasing the size of the bran particles in the bread gives more coarse bread because the flour fortification of the bran has a clear effect on the mechanical and chemical properties of the gluten network. 
Table 6-The volume, weight and specific volume of the experimental bread of the treatments under study

\begin{tabular}{|cccc|}
\hline Mills & Weight $(\mathrm{g})$ & Volume $\left(\mathrm{cm}^{3}\right)$ & Specific volume $\left(\mathrm{cm}^{3} / \mathrm{g}\right)$ \\
\hline Al-Brairi & 130.21 & 230 & 1.77 \\
\hline Al-Nesr & 132.76 & 220 & 1.66 \\
\hline Al-Doura & 120.74 & 170 & 1.41 \\
\hline L.S.D & $15.84 \mathrm{NS}$ & $23.97^{*}$ & $0.228^{*}$ \\
\hline
\end{tabular}

Table 7-The internal and external characteristics of experimental bread made of the flour produced by local mills

\begin{tabular}{|c|c|c|c|c|c|c|c|c|c|}
\hline Mills & $\begin{array}{l}\text { Specific } \\
\text { volume }\end{array}$ & $\begin{array}{l}\text { The } \\
\text { color } \\
\text { of } \\
\text { the } \\
\text { crust }\end{array}$ & $\begin{array}{c}\text { symmetry } \\
\text { of } \\
\text { form }\end{array}$ & $\begin{array}{l}\text { evenness } \\
\text { of } \\
\text { bake }\end{array}$ & $\begin{array}{l}\text { grain } \\
\text { of } \\
\text { crumb }\end{array}$ & $\begin{array}{l}\text { color } \\
\text { of } \\
\text { crumb }\end{array}$ & $\begin{array}{l}\text { texture } \\
\text { of } \\
\text { crumb }\end{array}$ & $\begin{array}{c}\text { aroma } \\
\text { and } \\
\text { taste }\end{array}$ & Total \\
\hline $\begin{array}{c}\text { Al- } \\
\text { Brairi }\end{array}$ & 30 & 9 & 5 & 4 & 6 & 6 & 6 & 16 & 82 \\
\hline $\begin{array}{c}\text { Al- } \\
\text { Nesr } \\
\end{array}$ & 28 & 9 & 5 & 4 & 6 & 7 & 6 & 16 & 81 \\
\hline $\begin{array}{c}\text { Al- } \\
\text { Doura } \\
\end{array}$ & 24 & 9 & 5 & 3 & 4 & 9 & 6 & 17 & 77 \\
\hline L.S.D & $\begin{array}{c}5.39 \\
*\end{array}$ & $\begin{array}{l}1.65 \\
\mathrm{NS}\end{array}$ & $\begin{array}{c}0.541 \\
\mathrm{NS}\end{array}$ & $\begin{array}{c}1.289 \\
\mathrm{NS}\end{array}$ & $\begin{array}{c}1.75 \\
*\end{array}$ & $\begin{array}{c}1.84 \\
*\end{array}$ & $\begin{array}{c}1.103 \\
\mathrm{NS}\end{array}$ & $\begin{array}{c}2 . .187 \\
\text { NS }\end{array}$ & $\begin{array}{c}4.38 \\
*\end{array}$ \\
\hline Degree & 30 & 10 & 5 & $\overline{5}$ & 10 & 10 & 10 & 20 & 100 \\
\hline
\end{tabular}

\section{References}

1. Ramadhan, H. Jaafar. 2017. Using Transglutaminase in Improving Local Wheat (AL-Rasheed Variety) Bread quality. A Thesis of Master of Science in Food Science. In The Department of Food Science. Collage of Agriculture. Baghdad University.Iraq.78-86.

2. Abadi, F.A. and Nasir, J.M. 2019. Effect of wet gluten addition on stalin characteristics of barley bread. Iraqi Journal of Agricultural Sciences. 50(1):390-397.

3. Almihyawi, E.K.H.2 018. Using Wheat Phytase in Reducing the Level of Phytate in Bread and Biscuit made from Local Whole Wheat Flour. To the council of the college of Agriculture at the University of Baghdad in partial fulfillment of the requirements for the degree of Master of Science in Agriculture (Food Science).

4. Reale, A., Konietzny, U., Coppola, R., Sorrentino, E. and Greiner, R. 2004. The importance of lactic acid bacteria for phytate degradation during cereal dough fermentation. J. Agri. Food Chem. 55: 2993-2997.

5. AACC. 2010. Approved Methods of the American Association of Cereal Chemists. St. Paul, Minnesota, U.S.A.

6. AACC. 2000. Approved Methods of the American Association of Cereal Chemists, 10th ed. AACC, St. Paul, MN, USA.

7. Alzubaidy, A. Hussain. 2009. Handbook of Cereal Technology .College of Agriculture . Baghdad University .

8. Latta , M. and Eskin, M. 1980 . A simple and rapid colorimetric method for phytate determination. J. Agric. Food Chem. 28, 1313-1315. Cited from Dhole ,V . J. and Reddy , K . S . (2015) . Genetic variation for phytic acid content in mungbean (vigna radiata l. wilczek). The Corp . J . 162 - 173.

9. Chen , P.S., Toribara, T.Y. and Warner, H . 1956. Micro determination of phosphorus. Anal. Chem. 28 (1956) 1756-1758. Cited from Dhole ,V . J . and Reddy, K . S . (2015) . Genetic variation for phytic acid content in mungbean (vigna radiata l. wilczek). The Corp . J . 162-173.

10. AACC . 1976 . Approved Methods of the American Association of Cereal Chemists. St. Paul, Minnesota, U.S.A . 
11. Sedaghati, M ., Kadivar , M ., Shahedi, M . and Soltanizadeh , N . 2011. Evaluation of the Effect of Fermentation, Hydrothermal Treatment, Soda, and Table Salt on Phytase Activity and Phytate Content of Three Iranian Wheat Cultivars . J. Ag. Sci. Tech. 13: 1065 - 1076.

12. Fiske, $\mathrm{C} . \mathrm{H}$. and Subbarow, Y. 1925. The colorimetric determination of phosphorus. The Journal of Biological Chemistry, 2: 375-400. Cited from Qasim, S. S. 2015. Production, Purification And Characterization Of Phytase From Aspergillus Tubingensis Ska By Solid State Fermentation For Application In Food Products . A Thesis of Doctorate in Agricultural Science in Food Science (Biotechnology). In The Department of Food Science and Biotechnology. Baghdad university: 38-39.

13. Zain El-abideen, M. Wageh. 1979. Study of install specification standard flour appropriate to the production of bread and Iraq's samoon. A Thesis of Master of Science in Food Science. In The Department of Food Science. College of Agriculture. Baghdad University: 64-73.

14. Požrl T., Kopjar M., Kurent I., Hribar J., Janeš A. and Simčič M. 2009. Phytate degradation during bread making: The influence of flour type and bread making procedures. Czech J. Food Sci., 27: 29-38.

15. Halverson, J., and Zeleny, L. 1988. Criteria of wheat quality. pages of $15-45$ In: wheat chemistry and technology Vol. 1, $3^{\text {rd }}$ edition. Y. Pomeranz, ed. Am. Assoc. cereal. chem., st . paul, MN.

16. Iuliana, B., Georgeta,S., Violeta, I. and Iuliana .A. 2010. Physicochemical and rheological analysis of flour mill streams. Cereal Chem, 87(2): 112-117.

17. Didar Z. 2011. Effect of Sourdough on Phytic Acid Content and Quality of Iranian Sangak Bread. J Nutr Food Sci. 1: 115. doi:10.4172/2155-

18. Schlemmer, U., Wenche, F., Rafel, M.Prieto and Felix, Grases. 2009. Phytate in foods and significance for humans: Food sources, intake, processing, bioavailability, protective role and analysis. Mol. Nut. Food Res.53: S330-S375 .

19. Hammood E.K. and Nasir, J.M. 2017. The Effect of Fermentation and Baking Processes on the Phytate Degradation During the Process of Manufacturing Whole Wheat Flour Bread. Iraqi Journal of Market Research and Consumer Protection. (IJMRCP), I.S.S.N:2071-3894, 9(2) .Doi prefix:10.28936.

20. AL-Rubbia, B.A.J. 2014. Effect of Processing Methods and fermentation on Phytic acid Content in Wheat and Its Products and studying the Rheological and Sensory Properties of Its. A thesis Submitted to the Council of the College of Agriculture at the University of Basrah in Partial Fulfillment of the Requirement for the Degree of Master in Food Science.

21. Lasztity R., Lasztity L. 1990. Phytic acid in cereal technology. In Advances in Cereal Science and Technology. American Association of Cereal Chemists Publishers, St. Paul: 309-371.

22. Fretzdorff B., Brummer J.M. 1992. Reduction of phytic acid during bread making of whole-meal breads. Cereal Chemistry, 69: 266-270.

23. Haraldsson, A. K., Veide, J., Andlid, T., Alminger, M. L. and Sandberg, A. S. 2005. Degradation of phytate by high-phytase Saccharomyces cervisiae strains during simulated gastrointestinal digestion. Journal of Agricultural and Food Chemistry, 54: 5438-5444.

24. Jamalian J. and Shekhol-Eslami Z. 2003. Effect of fermentation factors and extraction rate of flour on phytic acid content of Sangak and Lavash bread in Mashhad . Journal Science \& Technological Agriculture \& Nature Resource, Isfahan University, Iran.

25. Półtorak,A. and Zalewska, M. 2007. Phytic acid content in milled cereal products and breads. Food S.J. 51: 122-127.

26. Pyler, E. J. 1988. Baking Science \& Technology. Volume II . 3rd ed. USA . Sosland Publishing Company. 12: $38-45$.

27. Majzoobi, M., Farahnaky, A.Z., Nematolahi, Z., Mohammadi Hashemi, M. and Taghipour Ardakani, M.J. 2013. Effect of different levels and particle sizes of wheat bran on the quality of flat bread. J. Agr. Sci. Tech. 15: 115-123. 